\title{
PERANAN EKOWISATA BAGI KESEJAHTERAAN MASYARAKAT BAHOI KECAMATAN LIKUPANG BARAT
}

\author{
Reydi Marco Manahampi \\ Leonardus R. Rengkung \\ Yolanda P. I. Rori \\ Jean F. J. Timban
}

\begin{abstract}
This research aims to know more about the community's income and level of welfare after the implemetation of ecotourisem in Bahoi village, Likupang district, North Minahasa regency. This research was conducted in 4 months, from May to August 2015. Primary and secondary data was used, and data was collected through a survey. The sampling method used was Purposive Sampling that found 16 respondents (10\%) as the sample group, representing 160 families that reside in Bahoi village. Analysis shows that Dari ecotourism in Bahoi plays an important role in community life because locals feels its impact, both directly and indirectly, such as getting additional income, knowledge and experience. Based on this research it can be concluded that ecotourism activities in Bahoi plays a role in increasing the locals' income both directly and indirectly, and ecotourism activities has a positive impact on the welfare of the community and is expected to increase community welfare in Bahoi in general.
\end{abstract}

Keywords: Role of ecotourism, community, welfare.

\begin{abstract}
ABSTRAK
Penelitian ini bertujuan untuk mengetahui lebih jelas tentang pendapatan masyarakat setelah adanya ekowisata dan tingkat kesejahteraan masyarakat dengan adanya ekowisata di Desa Bahoi Kecamatan Likupang Barat Kabupaten Minahasa Utara. Penelitian ini di lakasanakan selama 4 bulan dari bulan Mei sampai Agustus 2015. Pengambilan data menggunakan metode survei dimana data yang digunakan adalah data primer dan sekunder. Untuk pengambilan sampel dilakukan dengan menggunakan metode Purposive Sampling kepada 16 responden (10\%) dengan banyaknya keluarga di desa Bahoi yaitu $160 \mathrm{KK}$. Dari hasil analisis yang diperoleh bahwa ekowisata di desa Bahoi sangatlah berperan penting terhadap kelangsungan hidup masyarakat karena dengan adanya ekowisata masyarakat dapat merasakan dampaknya secara langsung maupun tidak langsung seperti dapat menambah pendapatan, ilmu dan pengalaman yang lebih dari kegiatan ekowisata. Berdasarkan penelitian dapat di simpulkan bahwa kegiatan ekowisata yang dilaksanakan di desa Bahoi berperan dalam meningkatkan pendapatan masyarakat secara langsung maupun tidak langsung dan kegiatan ekowisata ini memberikan dampak positif untuk kesejahteraan masyarakat dan di harapkan ekowisata di desa Bahoi kedepannya dapat menaikan kesejahteraan masyarakat secara menyeluruh.
\end{abstract}

Kata kunci: Peranan ekowisata, Masyarakat, Kesejahteraan.

\section{PENDAHULUAN}

\section{Latar Belakang}

Kebijakan pembangunan pariwisata yang telah dilakukan lebih mengutamakan manfaat ekonomi sehingga mengakibatkan terabaikannya pelestarian lingkungan dan terpinggirkannya penduduk lokal. Degradasi lingkungan seperti berkurangnya keragaman hayati terjadi sebagai akibat dari pembangunan berbagai sarana akomodasi, transportasi dan perilaku wisatawan yang kurang ramah terhadap lingkungan. Selain itu pelaku 
wisata umumnya didominasi oleh pengusaha sedangkan penduduk lokal hanya menjadi pihak yang menjual tanah untuk kepentingan pengusaha dan kemudian terpinggirkan (Siregar, 2001).

Ekowisata merupakan perjalanan wisata ke suatu lingkungan baik alam yang alami maupun buatan serta budaya yang ada yang bersifat informatif dan partisipatif yang bertujuan untuk menjamin kelestarian alam dan sosial-budaya. Jadi, kegiatan ekowisata secara langsung memberi akses kepada semua orang untuk melihat, mengetahui, dan menikmati pengalaman alam, intelektual dan budaya masyarakat lokal. Ekowisata memberikan kesempatan bagi para wisatawan untuk menikmati keindahan alam dan budaya untuk mempelajari lebih jauh tentang pantingnya berbagai ragam mahluk hidup yang ada di dalamnya dan budaya lokal yang berkembang di kawasan tersebut. Kegiatan ekowisata dapat meningkatkan pendapatan untuk pelestarian alam yang dijadikan sebagai obyek wisata ekowisata dan menghasilkan keuntungan ekonomi bagi kehidupan masyarakat yang berada di daerah tersebut atau daerah setempat (Subadra, 2008).

Akhir-akhir ini negara berkembang seperti Indonesia mulai berpaling untuk lebih memberdayakan pengembangan wisata alternatif untuk mengantisipasi menurunnya kepopuleran pariwisata massal. Untuk itu perlu adanya alternatif pariwisata yang ramah terhadap lingkungan dan dapat meningkatkan kesejahteraan masyarakat terutama penduduk lokal (Iryenal, 2010)

Provinsi Sulawesi Utara dianugerahi dengan potensi sumber daya alam yang indah. Aneka ragam obyek dan daya tarik wisata tersebar di berbagai wilayah kabupaten dan kota. Berbagai obyek wisata eksotis tersebar mulai dari hamparan pemandangan pantai dan sawah, seni budaya yang khas dari pesisir hingga pegunungan, serta bahari yang kaya dengan bio diversity menjadi potensi unggulan. Sektor pariwisata menjadi salah satu sektor unggulan yang dapat menjadi penggerak roda perekonomian dalam pengembangan wilayah di Provinsi Sulawesi Utara. Hal ini karena sektor Periwisata merupakan sektor penting dalam upaya penerimaan Pendapatan Asli Daerah (PAD) yang cukup potensial. Pariwisata telah menjadi industri yang mampu mendatangkan devisa negara dan pen- erimaan asli daerah yang berimplikasi pada kesejahteraan masyarakat dalam berbagai sektor ekonomi.(Maramis 201)

Provinsi Sulawesi Utara yang terkenal dengan keindahan alamnya yang dapat menarik wisatawan untuk datang. Terdapat banyak wisata alam Sulawesi Utara yang potensial untuk dikembangkan. Di Sulawesi Utara ada gunung berapi bawah laut mahangetang. Gunung berapi bawah laut Mahangetang merupakan salah satu gunung berapi didunia yang masih aktif dan berada di perairan yang cukup dangkal sehingga anda bisa melihat salah satu kedahsyatan alam di Sulawesi Utara, Bukit Doa Tomohon anda akan disuguhi pemandangan alam yang sangat mempesona dan bisa memanjakan mata bagi siapa saja yang datang berkunjung ke tempat ini. Selain itu terdapat Waruga yang merupakan tempat wisata menarik lainnya di Sulawesi Utara. Waruga merupakan makam jaman purbakala yang terbuat dari bebatuan dan masih banyak lagi yang ada di Sulawesi Utara. Potensi ekowisata Sulawesi Utara ini belum terpublikasi dan dikembangkan secara optimal. Salah satu penyebab hal ini adalah kurangnya perhatian pemerintah dan masyarakat dalam mempromosikan dan memberdayakan sumber alam yang besar ini. Padahal, salah satu syarat tempat wisata agar banyak dikunjungi adalah, adanya pemandangan alam yang berkesan, ditunjang fasilitas umum dan akomodasi yang mudah dijangkau disertai promosi yang baik.(Daud .A ,2012)

Keberagaman sumber daya alam Sulawesi Utara merupakan kekuatan yang berpotensi untuk dikembangkan terutama dalam bidang ekowisata. Pengembangan ekowisata di Sulawesi Utara sangat penting karena tidak hanya berhubungan dengan wisata alam semata, melainkan juga berkaitan dengan peningkatan kesejahteraan masyarakat sekitar, konservasi sumber daya alam dan keberlangsungan pengembangan daerah.(Maramis 201)

Desa Bahoi berluas sekira 250 ha dan dihuni oleh sekira 480-an jiwa dari $131 \mathrm{KK}$, yang sebagian besarnya berprofesi sebagai petani dan nelayan. Bahoi terletak di Kecamatan Likupang Barat, Kabupaten Minahasa Utara, dengan bentang alam pesisir yang lengkap, yaitu ada ekosistem mangrove, padang lamun, dan terumbu karang (Tasidjawa. S, 2012). 
Desa Bahoi secara bertahap terus melengkapi perangkat ekowisatanya, seperti adanya homestay yang sesuai standard dan membentuk kelompok ekowisata yang membawahi kelompok kecil lain, seperti pemandu wisata, kerajinan, dan homestay. Konsep ekowisata yang dikembangkan di Bahoi adalah kegiatan wisata yang bertanggungjawab dengan menyelaraskan potensi alam dan budaya, serta masyarakat terlibat dalam pengelolaannya. Paket wisata yang disodorkan, antara lain perjalanan ke DPL di areal terumbu karang, atraksi budaya, seperti masamper dan empat wayer, serta makanan khas. Dampaknya, adalah dengan bertambahnya pendapatan masyarakat melalui kegiatan wisata, seperti homestay, kerajinan tangan, diving, snorkeling, trekking, dan penjualan makanan. Sementara keuntungan bagi desa ini, akan dikembalikan lagi untuk kegiatan konservasi, khususnya pemantapan pengeloaan DPL (Tasidjawa .S, 2012).

Namun demikian sampai saat ini belum di ketahui persis pengembangan ekowisata di Bahoi kedepan akan seperti apa karena masyarakat desa Bahoi sendiri belum sepenunya terlibat dalam pengembangan ekowisata di desa Bahoi, sampai saat ini yang berperan aktif hanyala masyarakat yang memiliki homestay,yang menjadi pemandu wisata dan kelompok kerajinan (Tasidjawa. S, 2012).

\section{Definisi dan Tujuan Ekowisata}

Ekowisata dapat diartikan sebagai kegiatan perjalanan wisata yang dikemas secara profesional, terlatih dan memuat unsur pendidikan, sebagai suatu sektor/usaha ekonomi yang mempertimbangkan warisan budaya, partisipasi dan kesejahteraan penduduk lokal serta upaya-upaya konservasi sumber daya alam dan lingkungan (Nugroho, 2004). Pengertian lain menurut Wisnu (2001) menyebutkan ekowisata sebagai suatu kegiatan wisata yang bertanggung jawab di tempattempat alami dan perjalanannya mendukung upaya pelestarian lingkungan (alam dan kebudayaan) dan meningkatkan kesejahteraan masyarakat setempat.

Istilah "ekowisata" juga dapat diartikan sebagai perjalanan oleh seorang turis ke daerah terpencil dengan tujuan menikmati dan mempelajari mengenai alam, sejarah dan budaya di suatu daerah, di mana pola wisatanya membantu ekonomi masyarakat lokal dan mendukung pelestarian alam (Hertanto, 2009).

Dalam ekowisata, prinsip tanggung jawab dan menghormati alam dan budaya setempat menjadi sangat penting. Wisatawan harus menyesuaikan diri dengan budaya dan situasi setempat, bukan sebaliknya.Wisatawan juga harus menyadari pentingnya pelestarian lingkungan dan menghormati budaya dari kawasan yang dikunjunginya (Mahdayani, 2009).

Sebagai pariwisata berkelanjutan tentunya ekowisata mempunyai tujuan sebagai berikut (Mahdayani, 2009).

1. Tercipta kemandirian ekonomi yaitu daya kompetisi dan kemandirian dari tempat pariwisata tersebut,sehingga akan tercipta keuntungan dan kemakmuran dalam jangka panjang

2. Tercipta kemakmuran masyarakat lokal yaitu kegiatan pariwisata menyumbangkan keuntungan secara finansial dan kemakmuran bagi masyarakat setempat

3. Meningkatkan kualitas dan kuantitas tenagatenaga kerja lokal dalam bidang pariwisata tanpa diskriminasi ras, jenis kelamin, dan lainlain

4. Memberikan keamanan kepuasan dan pengalaman kepada pengunjung tanpa ada diskriminasi

5. Memberikan masyarakat lokal suara/kuasa untuk menentukan sebuah keputusan dalam hal managemen dan pembangunan pariwisata di area tersebut

6. Meningkatkan kualitas hidup masyarakat lokal seperti membangun akses jalan, mendirikan fasilitas kesehatan dan lain-lain

7. Melestarikan kekayaan budidaya lokal, kegiatan pariwisata yang dilakukan tidak boleh membahayakan kelestarian budaya lokal

8. Tidak merusak dan mengubah bentang alam yang sudah ada, serta menghindari kerusakan fisik dan visual dari lingkungan

Mendukung usaha konservasi lingkungan alami, habitat, populasi hewan liar dan meminimalisasi kerusakannya

9. Menggunakan sumber daya alam, secara efisien untuk penyediaan fasilitas tersebut, 
seperti penggunaan listrik tenaga surya dan lain-lain.

10. Meminimalisasi polusi udara, air dan tanah yang dihasilkan dari perusahaan dan pengunjung.

\section{Prinsip dan Kriteria Ekowisata}

Tahun 2002 adalah tahun dimana dicanangkannya tahun ekowisata dan pegunungan di Indonesia. Dari berbagai workshop dan diskusi yang diselenggarakan pada tahun tersebut di berbagai daerah di Indonesia baik oleh pemerintah pusat maupun daerah, dirumuskan 5 (lima) prinsip dasar pengembangan ekowisata di Indonesia, yaitu (Mahdayani, 2009):

1. Pelestarian

2. Pendidikan

3. Pariwisata

4. Perekonomian

5. Partisipasi masyarakat setempat

\section{Pelestarian}

Prinsip kelestarian pada ekowisata adalah kegiatan ekowisata yang dilakukan tidak menimbulkan kerusakan dan pencemaran lingkungan dan budaya setempat. Salah satu cara menerapkan prinsip ini adalah dengan cara menggunakan sumber daya lokal yang hemat energi dan dikelolaoleh masyarakat sekitar. Tak hanya masyarakat, tapi wisatawan juga harus menghormati dan turut serta dalam pelestarian alam dan budaya pada daerah.

\section{Pendidikan}

Kegiatan pariwisata yang dilakukan sebaiknya memberikan unsur pendidikan. Ini bisa dilakukan dengan beberapa cara, antara lain dengan memberikan informasi menarik seperti nama dan manfaat tumbuhan dan hewan yang ada disekitar daerah wisata, dedaunan yang dipergunakan untuk obat atau dalam kehidupan sehari-hari, atau kepercayaan dan adat istiadat masyarakat lokal. Kegiatan pendidikan bagi wisatawan ini akan mendorong upaya pelestarian alam maupun budaya. Kegiatan ini dapat didukung oleh alat bantu seperti brosur, pamflet, buklet atau papan informasi.

\section{Pariwisata}

Pariwisata adalah aktivitas yang mengandung unsur kesenangan dengan berbagai motivasi wisatawan untuk mengunjungi suatu lokasi. Ekowisata juga harus mengandung unsur ini. Oleh karena itu, produk dan jasa pariwisata yang ada di daerah kita juga harus memberikan unsur kesenangan agar layak jual dan diterima oleh pasar.

\section{Ekonomi}

Ekowisata yang dijalankan harus memberikan pendapatan dan keuntungan (profit) sehingga dapat terus berkelanjutan. Untuk dapat mewujudkan hal itu,yang penting untuk dilakukan adalah memberikan pelayanan dan produk wisata terbaik dan berkualitas. Untuk dapat memberikan pelayanan dan produk wisata yang berkualitas, akan lebih baik apabila pendapatan dari pariwisata tidak hanya digunakan untuk kegiatan pelestarian di tingkat lokal tetapi juga membantu pengembangan pengetahuan masyarakat setempat, misalnya dengan pengembangan kemampuan melalui pelatihan demi meningkatkan jenis usaha/atraksi yang disajikan di tingkat desa.

\section{Partisipasi Masyarakat Setempat}

Partisipasi masyarakat akan timbul, ketika alam/budaya itu memberikan manfaat langsung/tidak langsung bagi masyarakat. Agar bisa memberikan manfaat maka alam/budaya itu harus dikelola dan dijaga. Begitulah hubungan timbal balik antara atraksi wisata-pengelolaan-manfaat yang diperoleh dari ekowisata dan partisipasi.Partisipasi masyarakat penting bagi suksesnya ekowisata di suatu daerah tujuan wisata. Hal ini bisadimulai dari diri kita sendiri. Jangan terlalu berharap pemerintah akan melakukan semua hal karena kita juga memiliki peranan yang sama dalam melakukan pembangunan di daerah kita. Partisipasi dalam kegiatan pariwisata akan memberikan manfaat langsung bagi kita, baik untuk pelestarian alam dan ekonomi. Bila kita yang menjaga alam tetap lestari danbersih, maka kita sendiri yang akan menikmati kelestarian alam tersebut, bila kita berperan dalam kegiatan pariwisata, maka kita juga yang akan mendapatkan manfaatnya secara ekonomi. 
Ekowisata mempunyai karakteristik yang spesifik karena adanya kepedulian pada pelestarian lingkungan dan pemberian manfaat ekonomi bagi masyarakat lokal (Hidayanti dkk, 2003). Oleh karenanya setiap kegiatan ekowisata harus mengikuti prinsip-prinsip pengelolaan yang berkelanjutan seperti:

1. Berbasis pada wisata alam

2. Menekankan pada kegiatan konservasi

3. Mengacu pada pembangunan pariwisata yang berkelanjutan

4. Berkaitan dengan kegiatan pengembangan pendidikan

5. Mengakomodasikan budaya lokal

6. Memberi manfaat pada ekonomi lokal

Menurut Achyaruddin (2011) kriteria ekowisata

Indonesia adalah ukuran suatu pengembangan dan penyelenggaraan kegiatan pariwisata di kawasan lindung, kawasan terbuka, kawasan binaan dan kawasan budaya yang mencukupi syarat-syarat:

- Konservasi

- Partisipasi

- Edukasi, Rekreasi dan Wisata

- Ekonomi

- Kendali

\section{Pengembangan Ekowisata dan Contoh Prakteknya di Indonesia}

Pada saat ini, ekowisata telah berkembang. Wisata ini tidak hanya sekedar untuk melakukan pengamatan burung, mengendarai kuda, penelusuran jejak di hutan belantara, tetapi telah terkait dengan konsep pelestarian hutan dan penduduk lokal. Tumbuh dari keprihatinan terhadap lingkungan, ekonomi dan sosial. Ekowisata ini tidak dapat dipisahkan dengan konservasi. Oleh karenanya, ekowisata disebut sebagai perjalanan wisata bertanggung jawab (Fandelli, 2000).

Kegiatan ekowisata yang sedang menjadi tren dunia dan diminati oleh wisatawan merupakan peluang bagi Indonesia, utamanya untuk meningkatkan pendapatan sektor wisata serta penyerapan tenaga kerja khususnya masyarakat lokal. Peningkatan kesejahteraan masyarakat, dapat diharapkan berpengaruh pada kepedulian terhadap kelestarian lokasi ekowisatanya (Hidayati dkk, 2003).
Dalam pengembangan ekowisata ada halhal yang harus diperhatikan, di antaranya (Achyaruddin, 2011):

1. Pemanfaatan lingkungan yang berkelanjutan

2. Peranserta masyarakat secara aktif

3. Pengembangan produk pariwisata yang memiliki nilai-nilai pendidikan dan pembelajaran dari lingkungan setempat

4. Pengembangan sarana dan prasarana yang Ramah Lingkungan

5. Pemasaran yang Bertanggung Jawab

6. Kordinasi dan kolaborasi Seluruh Pemangku Kepentingan.

Berikut adalah contoh-contoh praktek ekowisata yang sederhana dan mudah diterapkan oleh siapa saja di berbagai daerah tujuan wisata menurut Mahdayani (2003):

\section{Ekowisata di Hutan Bakau}

Mangrove Information Centre (MIC) yang berlokasi di Sanur, Bali merupakan kawasan hutan bakau yang menawarkan paket ekowisata kepada pengunjung. Aktivitas seperti trekking, pengamatan burung, naik sampan dan penanaman bakau merupakan tawaran yang diberikan kepada pengunjung. Pengunjung dapat juga mengadopsi bakau. Pengurus Manggrove Information Centre(MIC) kerap kali melakukan aktivitas penyadaran dan penyuluhan kepada masyarakat tentang pentingnya bakau bagi kawasan pesisir serta mengadakan kegiatan pelatihan kepada pelajar, guru sekolah, dan LSM.

\section{Kelompok Tenun yang Menggunakan Bahan Pewarna Alami}

Ibu-ibu penenun di Ndona, Kabupaten Ende di Flores mendirikan kelompok tenun bernama "Bou Sama Sama". Para wanita ini masih menggunakan pewarna alami yang diambil dari alam sekitar seperti mengkudu, nila serta berbagai jenis akar-akar pohon lainnya. Kain-kain tenun ikat yang dibuat dalam waktu 3, 6, sampai 12 bulan tersebut dijual langsung kepada wisatawan. Kelompok ini juga bekerja keras agar dapat menjalin kerjasama dengan pemilik galeri di Bali untuk memasarkan hasil kain tenun ikat buatan mereka. 


\section{Makanan Sehat Tanpa Penyedap Rasa dan Sayuran Organik}

Saat ini di berbagai kota besar di Indonesia dan kawasan wisata seperti Bali, Lombok, Yogyakarta banyak restoran menyajikan makanan sehat tanpa penyedap rasa serta menyajikan masakan dari sayuran organik yang dijual lebih mahal. Menu vegetarian(makanan non-daging) menjadi salah satu menu andalan di berbagai restoran di kawasan wisata tersebut.

\section{Peranan Ekowisata bagi Kesejahteraan Masyarakat}

Sejak tahun 1970-an organisasi konservasi mulai melihat ekowisata sebagai alternative pariwisata yang berbasis konservasi karena tidak merusak alam ataupun tidak ekstraktif dengan berdampak negative terhadap lingkungan seperti penebangan dan pertambangan. Ekowisata juga dianggap sejenis usaha yang berkelanjutan secara ekonomi dan lingkungan bagi masyarakat yang tinggal di dalam dan di sekitar kawasan konservasi (Hertanto, 2009).

Ekowisata diharapkan dapat membuka peluang bagi berkembangnya usaha kecil yang sesuai dengan skala lokasi tersebut. Oleh karenanya ada batasan yang sedikit kuat untuk ekowisata dimana secara ekonomi dan ekologi berpengaruh positif maka dibutuhkan adanya dukungan pemerintah dalam bentuk kebijakan yang memberi batasan akan pariwisata alam yang bertanggung jawab dan memberi manfaat secara ekonomi dan ekologi. Ekowisata dianggap mampu menjembatani jurangantarpengunjung, tempat tujuan wisata, operator, pemerintah dan lingkungan menjadi satu visi konservasi sebagai satu gerakan global (Hidayanti dkk, 2003).

Ekowisata sebagai pariwisata yang bertanggung jawab di daerah alami dan dilindungi atau tempat yang dirancang menurut kaidah alami dengan tujuan untuk melestarikan lingkungan maupun kebudayaan yang ada serta memberi kesempatan bagi masyarakat setempat dalam upaya meningkatkan kesejahteraannya. Dan memiliki daerah tujuan wisata, antara lain, kawasan konservasi, kawasan perlindungan, warisan budaya, fenomena alam, dan desa (Murdiyatmoko, 2012).
Salah satu tujuan pengembangan ekowisata di Indonesia adalah untuk memberi kesempatan kepada masyarakat desa yang bermukim di sekitar kawasan wisata untuk bisa menjadi pelaku wisata di desanya masing-masing agar pada gilirannya nanti dapat ikut menikmati hasil dari kegiatan bisnis pariwisata yang gemerlap itu, tidak hanya menjadi penonton semata seperti yang terjadi selama ini. Ekowisata juga membuka peluang ekonomi bagi masyarakat terlebih lagi apabila perjalanan wisata yang dilakukan menggunakan sumber daya lokal seperti transportasi, akomodasi dan jasa pemandu (Mahdayani, 2009).

Aspirasi dan motivasi masyarakat terhadap pembangunan kepariwisataan cukup tinggi, hal ini tercermin dari keinginan untuk menjadikan daerahnya sebagai daerah tujuan wisata yang menarik wisatawan baik wisatawan nusantara maupun mancanegara disamping keinginan tersebut, masyarkat berharap dapat meningkatkan kesejahteraan hidupnya dari perkembangan pariwisata di daerahnya tersebut (Brahmantyo \& Kusmayadi, 1999).

Untuk bisa menjadi pelaku ekowisata yang cakap, masyarakat harus memiliki keterampilan yang memadai dalam bidang pariwisata/ekowisata. Mereka harus diberi pelatihan yang relevan dengan kegiatan pariwisata. Sedangkan jenis pelatihan disesuaikan dengan produk ekowisata yang akan dikembangkan di desa. Beberapa manfaat ekowisata untuk peningkatan kesejahteraan masyarakat, yaitu (Brahmantyo \& Kusmayadi, 1999):

1. Masyarakat dapat menjadi kelompok pemandu wisata dan diberikan pelatihan, yang mencakup bahasa Inggris tingkat dasar, tingkat menengah sampai kepada tingkat mahir. Disamping itu mereka juga diberi pelatihan mengenai teknik memandu, pertolongan pertama pada kecelakaan, penyelamatan di air, dan kesehatan lingkungan.

2. Menjadi kelompok pembuat makanan, yaitu ibu-ibu yang dilatih mengenai teknik produksi makanan sehat yang nantinya akan bertugas untuk menyiapkan makanan dan minuman untuk disajikan atau dijual kepada wisatawan yang berkunjung ke desa. 
3. Menjadi kelompok nelayan diberikan pelatihan mengenai budidaya ikan di kolam terapung dan teknik penyelamatan di air.

4. Menjadi kelompok petani diberikan pelatihan mengenai pertanian organik dan pembuatan kompos.

5. Menjadi kelompok operator dan administrator ekowisata, diberikan pelatihan mengenai managemen usaha kecil, sistem administrasi keuangan, bahasa Inggris, pemasaran ekowisata, pemberdayaan komunitas dan kegiatan study banding.

Dengan demikian masyarakat dapat terlibat langsung dalam pengembangan ekowisata itu sendiri, yang secara umum mempuyai kriteria partisipasi, edukasi dan ekonomi yaitu: mewadahi tujuan-tujuan masyarakat, penghargaan terhadap kepemilikan lokal, berorientasi pada peningkatan kapasitas lokal, membangun kesadaran konservasi masyarakat, menambah wawasan dan pengetahuan masyarakat, membuka peluang usaha bagi masyarakat setempat dan membangkitkan ekonomi lokal, regional dan nasional (Murdiyatmoko, 2012).

Jadi ekowisata itu sendiri dapat menciptakan kesempatan kerja bagi masyarakat setempat, dan mengurangi kemiskinan dimana penghasilan ekowisata adalah dari jasa-jasa wisata untuk turis, misalnya: fee pemandu, ongkos transportasi, homestay, menjual kerajinan/cenderamata, dll. Selain itu ekowisata membawa dampak positif terhadap pelestarian lingkungan dan budaya asli setempat yang pada akhirnya diharapkan akan mampu menumbuhkan jati diri dan rasa bangga antar penduduk setempat yang tumbuh akibat peningkatan kegiatan ekowisata (Hertanto, 2009).

\section{Rumusan Masalah}

1. Bagaimana pendapatan masyarakat desa bahoi dengan adanya ekowisata?

2. Bagaimana tingkat kesejahteraan masyarakat dengan adanya ekowisata?

\section{Tujuan dan Manfaat}

Penelitian ini bertujuan untuk mengetahui lebih jelas tentang pendapatan masyarakat setelah adanya ekowisata dan tingkat kesejahteraan masyarakat dengan adanya ekowisata.

Manfaat dari penelitian ini adalah :

1. Bagi pemerintahhasil penelitian ini dapat di jadikan pedoman dalam pengambilan keputusan dan kebijakan.

2. Bagi stakeholder hasil penelitian ini dapat di jadikan bahan evaluasi dan rekomendasi dalam perjalanan pelaksanaan program Ekowisata di Desa Bahoi

\section{METODE PENELITIAN}

\section{Waktu dan Tempat}

Penelitian ini di laksanakan di desa Bahoi kecamatan Likupang Barat kabupaten Minahasa Utara selama 4 bulan yaitu dari bulan Mei sampai Agustus 2015.

\section{Metode Pengambilan Data}

Metode yang di gunakan dalam penelitian ini adalah wawancara. Data yang digunakan adalah data primer yang diambil secara langsung dengan menggunakan kuesioner dan data sekunder yang di dapat dari instansi pemerintah yaitu kantor desa Bahoi berupa data sosial ekonomi masyarakat dan BPS minahasa utara.

\section{Metode Pengambilan Sampel.}

Pengambilan sampel dilakukan dengan menggunakan "Purposive SamplingMethod". Singarimbun dan Effendi (1982) mengatakan bahwa Purposive SamplingMethod yaitu pengambilan sampel secara sengaja dengan menentukan bagian tertentu dalam populasi responden. Besarnya sampel yang harus diambil untuk mendapatkan data yang representatif minimal 5-10\% dari populasi. Sebagai sampel dalam penelitian ini diambil 16 responden dengan banyaknya keluarga di desa Bahoi yaitu 160 KK.

\section{Konsep dan Pengukuran Variabel}

Variabel - variabel yang diukur serta digunakan dalam penelitian ini adalah: 
a. Tinkat pendapatan/penghasilan keluarga, diukur dari besarnya tingkat pendapatan RT (Pekerjaan utama dan sampingan) (Rp/Bulan)

b. Tingkat pendidikan, Pendidikan yang diukur dari dua aspek yaitu formal (SD, SMP, SMA, Perguruan Tinggi) maupun non formal (Kursus bahasa asing maupun kursus Keterampilan )

c. Tingkat konsumsi/pengeluaran keluarga, diukur dari besarnya pengeluaran RT (Sandang, Pangan, Papan) (Rp/Bulan)

d. Kondisi perumahan, dilihat dari kondisi bangunan (atap, bilik, lantai, luas perumahan, status)

e. Jenis pekerjaan adalah yang dilakukan oleh masyarakat desa Bahoi berdasarkan jenis kegiatan ekowisata

Variabel yang di ukur akan dilihat perbandinganya sebelum dan setelah masuknya ekowisata di lokasi penelitian.

\section{Analisis Data}

Analisis data yang digunakan dalam penelitian ini adalah analisis data secara deskriptif dan di jelaskan dalam bentuk tabel.

\section{HASIL DAN PEMBAHASAN}

\section{Gambaran Umum Daerah Penelitian}

Desa Bahoi terletak di kecamatan Likupang Barat, daerah otonomi kabupaten Minahasa Utara yang letaknya di bagian paling utara pulau Sulawesi. Desa Bahoi berada pada ketinggian 3 sampai $75 \mathrm{~m}$ dari permukaan laut, memiliki suhu rata-rata $22^{\circ} \mathrm{C}$ sampai $24^{\circ} \mathrm{C}$ dan memperoleh curah hujan 80 sampai $100 \mathrm{~mm}$ per tahun, dengan curah hujan tertinggi terjadi sekitar bulan Oktober sampai bulan Februari.

\section{Potensi Sosial Ekonomi}

Penduduk

Penduduk adalah orang-orang yang berada di dalam suatu wilayah yang terikat oleh aturan-aturan yang berlaku dan saling berinteraksi satu sama lain secara terus menerus/kontinu. Dalam sosiologi, penduduk adalah kumpulan manusia yang menempati wilayah geografi dan ruang tertentu.Bicara mengenai penduduk tak pernah lepas dari pertumbuhan penduduk tersebut. Pertumbuhan penduduk dan jumlah penduduk di suatu wilayah di pengaruhi oleh 4 faktor yaitu kelahiran, kematian, migrasi masuk dan migrasi keluar.Faktor paling dominan yang mempengaruhi pertumbuhan penduduk adalah kelahiran dan kematian, sedangkan migrasi masuk dan migrasi keluar sangatlah rendah. Jumlah penduduk di suatu daerah akan mempengaruhi tingkat kesejahteraan masyarakat. Jumlah penduduk yang besar dalam hal ini, laju pertumbuhan penduduk mengikuti pertumbuhan eksponensial dan akan melampaui suplai makanan sehingga mengakibatkan kelaparan. Misalnya jika satu tidak terpenuhi/kehabisan stok makanan kemungkinan akan terjadinya kenaikan/lonjakan harga dan akan lebih membebani masyarakat yang berekonomi menengah ke bawah. Jika pertumbuhan penduduk terjadi maka akan terjadi seperti kelaparan dan kemiskinan yang akan menimbulkan masalah baru (kriminal). Akan tetapi, selain merugikan, juga ada keuntungannya; dengan pertumbuhan penduduk, rakyat jadi memiliki lebih banyak kesempatan bersosialisasi, bermusyawarah, dan bersilahturahmi untuk memperkuat kerukunan dan kesatuan.

Desa Bahoi yang terletak di Kecamatan Likupang Barat, Kabupaten Minahasa Utara memiliki jumlah penduduk sebanyak 543 jiwa dengan jumlah KK (kepala keluarga) $160 \mathrm{KK}$. Tabel 1 menunjukan jumlah penduduk desa Bahoi berdasarkan jenis kelamin.

Tabel 1. Jumlah penduduk desa Bahoi berdasarkan jenis kelamin

\begin{tabular}{ccc}
\hline No & Jenis kelamin & $\begin{array}{c}\text { Jumlah } \\
\text { (orang) }\end{array}$ \\
\hline 1 & Laki - laki & 296 \\
2 & Perempuan & 247 \\
\hline & Jumlah & 543
\end{tabular}

Sumber data: Kantor Desa Bahoi, 2015

Tingkat Pendidikan

Pendidikan merupakan upaya dalam membimbing manusia yang belum dewasa ke arah 
kedewasaan. Pendidikan adalah suatu usaha dalam menolong anak untuk melakukan tugas-tugas hidupnya agar mandiri dan bertanggung jawab secara susila. Pendidikan juga diartikan sebagai usaha untuk mencapai penentuan diri dan tanggung jawab. Pembangunan pendidikan menjadi salah satu program prioritas, baik bagi pemerintah desa Bahoi maupun masyarakat secara umum. Tabel 2 menunjukan tingkat pendidikan masyarakat desa Bahoi.

Tabel 2. Jumlah Penduduk Desa Bahoi Menurut Tingkat Pendidikan

\begin{tabular}{lccc}
\hline No & Pendidikan & Orang & $\begin{array}{l}\text { Persentase } \\
(\%)\end{array}$ \\
\hline 1 & $S D$ & 285 & 54 \\
2 & SMP & 180 & 34 \\
3 & SMA & 48 & 9 \\
4 & Perguruan & 16 & 3 \\
\hline Total & Tinggi & & \\
\hline
\end{tabular}

Berdasarkan Tabel 2 dapat dilihat bahwa jenjang pendidikan tertinggi di desa Bahoi adalah perguruan tinggi, namun jumlahnya cukup rendah, yaitu 16 jiwa (3\%), sedangkan jumlah penduduk terbesar berada pada jenis pendidikan SD, yaitu 285 jiwa (54\%). Sekalipun jumlah penduduk yang berpendidikan perguruan tinggi sangat kecil, namun tiap tahunnya ekowisata di desa Bahoi terjadi peningkatan. Melalui data di atas dapat dikatakan bahwa wajib belajar di desa Bahoi belum berjalan dengan baik karena masih banyak penduduk yang hanya lulusan SD. Hal ini disebabkan masih kurangnya fasilitas pendidikan tingkat SMP dan SMA. Masyarakat yang ingin melanjutkan sekolah harus menambah biaya transpor karna mereka harus pergi keluar desa dan bersekolah di desa Likupang. Data ini belum termasuk penduduk usia balita.

Mata Pencaharian / Pekerjaan

Mata pencaharian atau pekerjaan merupakan hal yang sangat penting bagi manusia, karena tanpa pekerjaan kita akan mengalami kesulitan da- lam hidup kita. Kita memiliki akal dan kebijaksanaan, dengan kebijaksanaan kita dapat mengembangkan kemampuan, memperbaiki, membuat sesuatu atau memilih pekerjaan yang kita inginkan. Memilih pekerjaan yang akan kita kerjakan penting sekali sebab bila kita salah memilih perkerjaan, kita akan selalu merasa tidak puas dan menderita. Pekerjaan adalah sesuatu yang dilakukan oleh manusia untuk tujuan tertentu yang dilakukan dengan cara yang baik dan benar. Manusia perlu bekerja untuk mempertahankan hidupnya. Dengan bekerja seseorang akan mendapatkan uang. Uang yang diperoleh dari hasil bekerja tersebut digunakan untuk memenuhi kebutuhan hidup.

Tabel 3 Jumlah penduduk Desa Bahoi Menurut Mata Pencaharian

\begin{tabular}{lccc}
\hline No & $\begin{array}{c}\text { Jenis } \\
\text { Mata } \\
\text { Pekerjaan } \\
\text { Petani }\end{array}$ & Orang & $\begin{array}{c}\text { Persentase } \\
(\%)\end{array}$ \\
1 & Nelayan & 325 & 30 \\
\hline 2 & Pengusaha & 16 & 60 \\
3 & PNS, TNI, & 10 & 2 \\
4 & Polri & & \\
& Pensiunan & 10 & 2 \\
5 & Supir & 10 & 2 \\
6 & Lain-lain & 5 & 1 \\
7 & & $\mathbf{5 2 2}$ & $\mathbf{1 0 0}$ \\
\cline { 1 - 2 } & &
\end{tabular}

Sumber data: Kantor Desa Bahoi, 2015.

Jenis pekerjaan ada bermacam-macam. Ada pekerjaan menghasilkan barang dan ada pula pekerjaan yang menyediakan jasa. Pekerjaan menghasilkan barang dapat dilihat hasilnya. Adapun pekerjaan memberikan jasa hanya dapat dirasakan manfaat dari layanannya.Pekerjaan penduduk desa Bahoi cukup beragam, yaitu sebagai petani, PNS, TNI, Polri, pengusaha, pensiunan, sopir, dan lain-lain. Tabel 3 menunjukan mata pencaharian penduduk di desa Bahoi.

Dari data tabel 3 dapat dilihat bahwa jumlah penduduk di desa Bahoi yang bekerja sebagai petani 
adalah $30 \%$, nelayan $60 \%$, pengusaha $3 \%$, PNS, TNI, Polri $2 \%$, pensiunan $2 \%$, supir $2 \%$, sementara yang memiliki pekerjaan lain adalah $1 \%$. Sedang sisanya usia sekolah 21 orang. Berdasarkan data di atas bahwa pekerjaan masyarakat desa Bahoi paling banyak adalah sebagai nelayan denga persentase $60 \%$. Hal ini disebabkan karena masih banyak masyarakat desa Bahoi yang hanya lulusan sekolah dasar (SD) sehingga untuk bekerja PNS atau bekerja di perusahaan minimal masyarakat harus memiliki ijazah Sekolah Menengah Atas (SMA). Selain itu juga desa Bahoi terletak di pesisir pantai jadi kebanyakan masyarakat hanya menggantungkan mata pencaharian mereka sebagai nelayan dan hasil laut lainya.

\section{Karakteristik Responden}

\section{Umur Kepala Keluarga}

Umur adalah waktu atau bertambahnya hari sejak lahir sampai akhir hidup. Usia sangat mempengaruhi seseorang; semakin bertambah usia maka semakin banyak pengetahuan yang di dapat.Umur dapat mempengaruhi kemampuan seseorang untuk bekerja secara fisik serta dapat menentukan persepsi seseorang.

Tabel 4. Jumlah Responden menurut Umur

\begin{tabular}{lccc}
\hline NO & $\begin{array}{c}\text { Umur } \\
\text { (Tahun) }\end{array}$ & $\begin{array}{c}\text { Jumlah Re- } \\
\text { sponden }\end{array}$ & $\begin{array}{c}\text { Persentase } \\
\text { ( \% ) }\end{array}$ \\
\hline & & (Orang ) & \\
1 & $15-35$ & 1 & 6,25 \\
3 & $36-55$ & 11 & 68,75 \\
3 & $>56$ & 4 & 25 \\
\hline Jumlah & & $\mathbf{1 6}$ & $\mathbf{1 0 0}$ \\
\hline
\end{tabular}

Umur juga dapat mempengaruhi produktivitas kerja dan peranan dalam proses pengambilan keputusan berbagai pekerjaan yang dilakukan. Umur produktif berada antara 15 tahun hingga 55 tahun. Berdasarkan penelitian, komposisi umur responden dapat disajikan pada Tabel 4.

Dari tabel 4 dapat dilihat bahwa $75 \%$ kepala keluarga di desa Bahoi masuk dalam umur produktif dan hanya $25 \%$ saja kepala keluarga yang memiliki umur yang tidak produktif. Berdasarkan wawancara yang dilakukan dengan responden, masyarakat di desa Bahoi umumnya menikah di usia yang sudah tergolong produktif. Kepala keluarga yang sudah tidak produktif juga memiliki anggota keluarga yang masuk dalam usia produktif

Jumlah Anggota Keluarga Responden

Keluarga sebagai unit masyarakat terkecil biasanya terdiri dari ayah, ibu dan anak-anak. Jumlah angota keluarga berpengaruh pada distribusi pendapatan. Jumlah tanggungan keluarga responden dijelaskan pada tabel 5 .

Tabel 5 menunjukan sebagian besar responden memiliki anggota keluarga sebanyak 4 orang, yaitu 6 rumah tangga $(37,5 \%)$ dari total rumah tangga responden, sedangkan jumlah anggota keluarga paling sedikit sebanyak 3 orang pada 2 rumah tangga responden (12,5\%). Dari hasil wawancara didapati bahwa keluarga di desa Bahoi sebagian besar telah menggunakan KB sehingga jumlah anggota keluarga tidak melebihi dari jumlah keluarga berencana (KB). Di samping itu, rata-rata masyarakat di desa Bahoi masih tergolong masyarakat yang hidup berkecukupan sehingga untuk memiliki jumlah anggota keluarga yang banyak, pasti pengeluaran pun akan bertambah.

Tabel 5. Jumlah responden menurut jumlah anggota keluarga

\begin{tabular}{cccc}
\hline No & $\begin{array}{c}\text { Jumlah } \\
\text { Anggota } \\
\text { Keluarga } \\
\text { (orang) }\end{array}$ & $\begin{array}{c}\text { Jumlah Re- } \\
\text { sponden } \\
\text { (Orang) }\end{array}$ & $\begin{array}{c}\text { Persentase } \\
(\%)\end{array}$ \\
\hline 1 & 2 & 3 & 18,75 \\
2 & 3 & 2 & 12,5 \\
3 & 4 & 6 & 37,5 \\
4 & $>5$ & 5 & 31,25 \\
\hline
\end{tabular}

\begin{tabular}{lll}
\hline Jumlah & 16 & 100
\end{tabular}

Sumber: Diolah dari Data Primer, 2015. 


\section{Potensi dan Pemanfaatan Sumberdaya alam}

Keberadaan desa Bahoi yang kaya akan sumber daya alam mendorong penduduk untuk memanfaatkan sumber daya yang ada untuk menunjang kelangsungan hidupnya. Aktifitas kelautan merupakan mata pencarian terbesar masyarakat (nelayan). Oleh karena itu, laut khususnya pantai memegang peranan penting dalam menunjang perekonomian setempat. Adapun aktivitas pemanfaatan pantai dan perairan pantai antara lain untuk budidaya lobster, penangkapan ikan serta wisata bawah laut. Potensi sumberdaya alam yang terdapat di desa Bahoi berupa ekosistem terumbu karang beserta ikan yang berasosiasi dengannya, ekosistem mangrove, ekosistem rumput laut dan padang lamun serta potensi perikanan, yaitu dapat digambarkan sebagai berikut:

Terumbu Karang

Keindahan terumbu karang dan ikan karang merupakan daya tarik utama wisata bawah laut di Bahoi. Formasi pertumbuhan karang berdasarkan bentuk dan hubungan perbatasan tumbuhnya terumbu karang dengan dataran Bahoi membuat desa Bahoi terkenal akan karangnya dan mampu memikat para wisatawan lokal maupun mancanegara.

\section{Mangrove}

Ekosistem mangrove yang ada di desa Bahoi memiliki luas 10 ha. Dari data sekunder (2015) yang diperoleh, terdapat 11 jenis pohon mangrove yang tergolong dalam 6 famili di samping 1 jenis semak. Jenis mangrove yang dominan ditemukan adalah Rhizophora, Avicennia, Aegiceras, Excoecaria, Lumnizeria, Scyphiphora, Ceriops, Xylocarpus, Sonneratia, Bruguiera dan satu jenis yang tidak teridentifikasi. Jenis mangrove yang menonjol di desa Bahoi adalah tipe Rhizophora dan Sonneratia yang banyak dijumpai di sisi Bahoi yang agak terlindung dan langsung menghadap ke laut. Rhizophora yang dominan terdapat di sini mencapai tinggi berkisar antara 8-15 m dengan diameter $18-25 \mathrm{~cm}$. Di sini berasosiasi dengan Sonneratia, dengan ketinggian pohon dapat mencapai $10 \mathrm{~m}$ dan diameter pohon rata-rata $20 \mathrm{~cm}$.

Kondisi hutan mangrove di lokasi penelitian masih relatif baik, dengan ketebalan mencapai 400 meter dari garis pantai. Regenerasi komunitas mangrove di Desa Bahoi dikategorikan cukup baik. Ketebalan 0 meter terdapat di daerah terbuka yang secara khusus dimanfaatkan untuk jalan masuk dari perairan ke daratan yang terletak di kawasan mangrove. Adapun akses jalan masuk dari ujung perkampungan yang telah dibuat sedemikian rupa oleh masyarakat dengan menggunakan jembatan sepanjang 100 meter yang melewati tengah hutan mangrove. Kondisi hutan mangrove yang relatif baik ini tidak terlepas dari partisipasi aktif masyarakat yang sangat memperhatikan kelestarian hutan mangrove dengan adanya Peraturan Desa yang dipatuhi.

Perikanan dan Budidaya Laut

Sub-sektor perikanan merupakan usaha yang paling menonjol di desa Bahoi. Jenis usaha perikanan yang terdapat di wilayah ini adalah penangkaran ikan di perairan laut dan budidaya lobster.

\section{Kegiatan Ekowisata di Desa Bahoi}

Desa Bahoi merupakan desa kecil di wilayah pesisir Sulawesi Utara, termasuk dalam wilayah administrasi kecamatan Likupang Barat, kabupaten Minahasa Utara. Separuh dari penduduk desa Bahoi mengandalkan pekerjaannya sebagai nelayan. Adanya hamparan hutan mangrove yang luasnya sekitar 10 ha atau $30 \%$ dari total luas desa Bahoi serta hamparan terumbu karang yang luas berfungsi sebagai tempat pemijahan ikan membuat penduduk desa Bahoi yakin bahwa hutan mangrove dan terumbu karang memiliki peranan penting bagi kelestarian lingkungan, sehingga perlu untuk senantiasa dijaga dan dirawat keberadaannya demi kelangsungan perekonomian masyarakat desa. 
Dimulai sejak masuknya Program Nasional Pemberdayaan Masyarakat Lingkungan Mandiri Pedesaan (PNPM LMP), masyarakat di desa Bahoi mulai merintis kegiatan pelestarian dan perlindungan kawasan pesisir. Usulan kegiatan lingkungan yang kemudian didanai dari PNPM LMP erat kaitannya dengan kegiatan-kegitan konservasi untuk perlindungan dan pelestarian kawasan pesisir. Kegiatan konservasi perlindungan kawasan pesisir yang dikembangkan oleh masayarakat adalah dengan menetapkan Daerah Perlindungan Laut (DPL), di mana kawasan tersebut telah dikuatkan dengan aturan lokal berupa Peraturan Desa (Perdes) tentang Daerah Perlindungan Laut. Dengan ditetapkannya kawasan DPL berarti di daerah tersebut telah disepakati oleh masyarakat desa Bahoi sebagai daerah "larang ambil" yang secara permanen tertutup bagi kegitan yang bersifat ekstraktif kecuali untuk kegitan-kegitan penelitian dan wisata terbatas seperti snorkeling dan menyelam.

Perlahan masyarakat desa Bahoi telah menikmati hasil dengan tersedianya DPL. Ikan dapat berkembang biak dengan baik dan keindahan terumbu karangnya terjaga, menjadikan kawasan DPL menjadi salah satu daerah yang mulai dilirik turis lokal maupun asing untuk melakukan kegitan menyelam. Konon keindahan alam bawah laut yang ada di desa Bahoi tak kalah indahnya dengan Taman Laut Nasional Bunaken. Secara partisipatif dengan melibatkan berbagai unsur masyarakat mulai dari tokoh masyarakat, tokoh adat, tokoh agama dan kelompok masyarakat lainnya, usaha pengembangan ekowisata bawah laut desa Bahoi menjadi pilihan kegiatan yang perlu dikembangkan selanjutnya demi tercapai kelestarian kawasan pesisir yang pada akhirnya perekonomian masyarakat dapat meningkat.

Kegiatan ekowisata di desa Bahoi berlangsung sejak tahun 2002. Kegiatan ekowisata mulai marak tahun 2012 dengan adanya peningkatan ragam aktivitas ekowisata yang ada di Desa Bahoi. Aktivitas semakin berkembang dengan di tetapkannya desa Bahoi sebagai Desa Ekowisata, dengan objek wisata alam yang memanfaatkan keindahan alam dan tidak mengubah bentang alam yang ada untuk pariwisata. Paket wisata yang disodorkan an- tara lain perjalanan ke DPL (Daerah Perlindungan Laut) di areal terumbu karang, wisata mangrove, diving, snorkeling, atraksi budaya seperti Masamper dan Empat Wayer, serta berbagai makanan khas. Sebagai desa pesisir laut, masyarakat desa Bahoi hidup dari hasil laut, sehingga laut perlu dijaga keberadaanya melalui Daerah Perlindungan Laut.

Saat ini masyarakat sudah mulai menerima manfaat dari keberadaan DPL sebagai bank ikan. Melindungi laut merupakan upaya tidak hanya untuk kehidupan saat ini namun juga untuk kehidupan generasi yang akan datang. Pemerintah desa Bahoi juga telah memasukkan pengembangan ekowisata dalam RPJMDes (Rencana Pembangunan Jangka Menengah Desa) sebagai program pariwisata berkelanjutan dan konservasi sekaligus pemberdayaan ekonomi berbasis masyarakat setempat. Pemerintah desa Bahoi telah mengeluarkan Peraturan Desa No.02/2010 tentang pengelolaan wilayah pesisir dan laut untuk keberlanjutan DPL. Ekowisata dibuat untuk memanfaatkan daerah penyangga DPL dan saat ini telah tersedia infrastruktur sederhana meliputi penginapan, pemandu wisata, souvenir. Modalitas sosial ini sangat baik, tetapi untuk implementasi yang lebih baik masih perlu bantuan teknis dan dukungan kebijakan dari Pemerintah Daerah dan LSM. Tantangan pengembangan ekowisata desa Bahoi adalah perlunya sinergi program Pemda dan desa, serta pengembangan infrastruktur yang memperhatikan aspek lingkungan. Kelompok ekowisata dan DPL juga harus ada penguatan kapasitas agar lebih siap menerima wisatawan. Program desa juga diharapkan menginisiasi kemandirian masyarakat dalam menjalankan pengelolaan DPL dan ekowisata yang berkelanjutan.

\section{Indikator Yang Menggambarkan Kesejahteraan Masyarakat}

Kesejahteraan meliputi seluruh bidang kehidupan manusia. Mulai dari ekonomi, sosial, budaya, iptek, hankamnas, dan lain sebagainya. Bidang-bidang kehidupan tersebut meliputi jumlah dan jangkauan pelayanannya. Pemerintah memiliki kewajiban utama dalam rangka meningkatkan kesejahteraan rakyatnya. Untuk mengukur tingkat kesejahteraan ada bebarapa indikator yang perluh di 
perhatikan. Berikut adalah indikator yang mengukur tingkat kesejahteraan masyarakat.

\section{Tingkat Pendapatan Rumah Tangga}

Pendapatan rumah tangga dilihat dari dua sumber, yakni sumber pendapatan utama dan sumber pendapatan tambahan. Sumber pendapatan utama berasal dari pekerjaan atau profesi masyarakat, sedangkan pendapatan tambahan didapat dengan memanfaatkan potensi ekowisata yang ada.

Tabel 6. Tingkat Pendapatan Rumah Tangga

\begin{tabular}{crrc}
\hline \multirow{2}{*}{ NO } & \multicolumn{2}{c}{ RESPONDEN } & \multirow{2}{*}{$\%$} \\
& \multicolumn{1}{c}{ SEBELUM } & \multicolumn{1}{c}{ SESUDAH } & \\
\hline 1 & $3,965,000.00$ & $4,465,000.00$ & 11,1 \\
2 & $2,000,000.00$ & $2,200,000.00$ & 9,09 \\
3 & $2,000,000.00$ & $2,300,000.00$ & 13,6 \\
4 & $500,000.00$ & $900,000.00$ & 44,4 \\
5 & $4,000,000.00$ & $4,500,000.00$ & 11,1 \\
6 & $500,000.00$ & $900,000.00$ & 44,4 \\
7 & $500,000.00$ & $800,000.00$ & 37,5 \\
8 & $1,500,000.00$ & $1,700,000.00$ & 11,7 \\
9 & $3,000,000.00$ & $3,500,000.00$ & 14,2 \\
10 & $1,000,000.00$ & $1,400,000.00$ & 28,5 \\
11 & $1,000,000.00$ & $1,300,000.00$ & 23,07 \\
12 & $900,000.00$ & $1,300,000.00$ & 30,7 \\
13 & $3,000,000.00$ & $3,600,000.00$ & 16,6 \\
14 & $600,000.00$ & $1,000,000.00$ & 40 \\
15 & $3,500,000.00$ & $4,100,000.00$ & 14,6 \\
16 & $400,000.00$ & $900,000.00$ & 55,5 \\
\hline Jumlah & $28,365,000.00$ & $34,865,000.00$ & \\
Rata - & & & 40,00 \\
rata & $1,772,812.50$ & $2,179,062.50$ & \\
\hline
\end{tabular}

Sumber: Diolah dari Data Primer, 2015.

Dari hasil penelitian diperoleh, usaha sambilan masyarakat untuk meningkatkan pendapatannya melalui pemanfaatan potensi ekowisata di desa Bahoi adalah sebagai jasa pedagang kerajinan tangan, penjualan makanan, penyewaan perahu, pemandu diving dan home stay yang dilakukan kepala keluarga maupun anggota keluarga yang lain. Hasil yang diperoleh dari usaha sambilan dengan pengembangan ekowisata memberikan manfaat yang cukup positif bagi masyarakat karena selain memberikan tambahan penghasilan juga meningkatkan pendapatan asli daerah. Berdasarkan tinggkat pendapatan dapat dipakai sebagai salah satu indikator untuk melihat tingkat kesejahteraan.

Berdasarkan hasil penelitian pendapatan rata-rata rumah tangga masyarakat dapat dilihat dalam Tabel 6. Tabel 6 menunjukan pendapatan re- sponden sebelum adanya ekowisata dan setelah ada ekowisata. Dapat dilihat rata-rata pendapatan responden sebelum adanya ekowisata adalah Rp1.772.812,50 dan rata-rata pendapatn responden setelah adanya ekowisata adalah Rp2.179.062,50. Dengan demikian dapat disimpulkan bahwa setelah masuknya ekowisata dan masyarakat terlibat di dalamnya seperti menjadi pemandu wisata, home stay, penjualan makanan dan pembuatan cenderamata, pendapatan masyarakat terjadi peningkatan dengan rata-rata peningkatan sebesar $40,00 \%$.

\section{Tingkat Pendidikan}

Pendidikan merupakan salah satu sarana untuk meningkatkan kecerdasan dan keterampilan manusia. Peningkatan dalam bidang pendidikan dapat mengentaskan penduduk dari kemiskinan baik secara langsung maupun tidak langsung, yaitu melalui perbaikan pendapatan, nutrisi dan pengeluaran keluarga. Pendidikan dapat membuat seseorang berpikir secara rasional dan sistematis. Seseorang yang memiliki pendidikan lebih tinggi tentunya akan lebih mampu menganalisis manfaat yang akan diperolehnya. Pendidikan sangat berperan dalam menciptakan perubahan dalam kehidupan masyarakat. Berdasarkan hasil penelitian, tingkat pendidikan responden bervariasi mulai dari tingkat Sekolah Dasar (SD), Sekolah Menengah Pertama (SMP) dan Sekolah Menengah Atas (SMA). Tingkat pendidikan responden dapat dilihat pada Tabel 7.

Tabel 7 menunjukan bahwa responden pelaku ekowisata desa Bahoi terbanyak berada pada tingkat pendidikan SMA, yaitu sebanyak 6 orang $(37,5 \%)$. Berdasarkan wawancara dengan responden hal ini disebabkan bahwa saat masih duduk di bangku SMA responden telah bekerja sehingga mereka memilih untuk terus bekerja daripada melanjutkan ke perguruan tinggi, sedangkan pada tingkat SMP terdapat 4 responden $(12,5 \%)$ dan tingkat SD terdapat 4 orang (25\%). Ini terjadi karena mereka tidak mampu membayar biaya lanjut sekolah sehingga mereka memutuskan untuk bekerja. Tingkat pendidikan responden yang paling sedikit yaitu pada tingkat pendidikan perguruan tinggi di mana hanya terdapat 2 orang $(12,5 \%)$. Hal ini disebabkan karena responden yang melanjutkan sekolah sampai pada tingkat perguruan tinggi adalah responden yang berkecukupan dalam hal 
ekonomi sehingga responden mampu untuk melanjutkan sekolah ke tingkat perguruan tinggi.

Tabel 7. Tingkat Pendidikan Responden

\begin{tabular}{cccc}
\hline No & $\begin{array}{c}\text { Tingkat } \\
\text { Pendidi- } \\
\text { kan }\end{array}$ & $\begin{array}{c}\text { Jumlah Re- } \\
\text { sponden } \\
\text { ( Orang ) }\end{array}$ & $(\%)$ \\
\hline 1 & SD & 4 & 25 \\
2 & SMP & 4 & 25 \\
3 & SMA & 6 & 37,5 \\
4 & Pergurua & 2 & 12. \\
& n Tinggi & & 100 \\
\hline Jumlah & & 16 & \\
\hline
\end{tabular}

Sumber: Diolah dari Data Primer, 2015

\section{Tingkat Konsumsi/Pengeluaran Rumah Tangga}

Pengeluaran konsumsi rumah tangga adalah nilai belanja yang dilakukan oleh rumah tangga untuk membeli berbagai jenis kebutuhannya. Pendapatan yang diterima rumah tangga akan digunakan untuk membeli makanan, membiayai jasa angkutan, membayar pendidikan anak, membayar sewa rumah dan membeli kendaraan. Barangbarang tersebut dibeli rumah tangga untuk memenuhi kebutuhannya, dan pembelanjaan tersebut dinamakan konsumsi.

Pengeluaran konsumsi yang dilakukan oleh seluruh rumah tangga dalam perekonomian tergantung kepada pendapatan yang mereka terima. Makin besar pendapatan mereka, makin besar pula pengeluaran konsumsi mereka. Sifat penting lainya dari konsumsi rumah tangga adalah hanya sebagian saja dari pendapatan yang mereka terima yang akan digunakan untuk pengeluaran konsumsi. Secara garis besar pengeluaran rumah tangga masyarakat desa Bahoi terdiri dari dua jenis pengeluaran, yaitu pengeluaran untuk pangan dan bukan pangan. Besarnya jumlah kedua jenis pengeluaran ini sangat di pengaruhi oleh kebutuhan hidup dan pola konsumsi rumah tangga masyarakat desa Bahoi itu sendiri. Kebutuhan hidup rumah tangga masyarakat Bahoi adalah pemenuhan kebutuhan dasar manusia yang terdiri dari sandang, pangan, perumahan, kesehatan, dan pendidikan. Kebutuhan dasar ini menurut BPS dapat dijelaskan sebagai indikator pengeluaran per kapita penduduk daerah perkotaan dan pedesaan.Berdasarkan hasil penelitian ini jumlah pengeluaran rata-rata rumah tangga masyarakat dapat dilihat dalam tabel 8 .

Tabel 8. Tingkat Konsumsi / Pengeluaran Rumah Tangga.

\begin{tabular}{cccccccccc}
\hline \multirow{2}{*}{ NO } & \multicolumn{2}{c}{ RESPONDEN } & \multicolumn{6}{c}{ JENIS PENGELUARAN DAN PRESENTASE (\%) } \\
& PENDAPATAN & PENGELUARAN & $(\%)$ & SANDANG & $\%$ & PANGAN & $\%$ & PAPAN & $\%$ \\
\hline 1 & $4,465,000.00$ & $4,000,000.00$ & 89,5 & $2,000,000.00$ & 50 & $1,000,000.00$ & 25 & $1,000,000.00$ & 25 \\
2 & $2,200,000.00$ & $1,700,000.00$ & 77,2 & $1,000,000.00$ & 58,8 & $700,000.00$ & 41,2 & - & - \\
3 & $2,300,000.00$ & $1,500,000.00$ & 65,2 & $1,000,000.00$ & 66,6 & $500,000.00$ & 33,4 & - & - \\
4 & $900,000.00$ & $500,000.00$ & 55,5 & $300,000.00$ & 60 & $200,000.00$ & 40 & - & - \\
5 & $4,500,000.00$ & $3,000,000.00$ & 66,6 & $1,000,000.00$ & 33,3 & $1,000,000.00$ & 33,3 & $1,000,000.00$ & 33,3 \\
6 & $900,000.00$ & $500,000.00$ & 55,5 & $300,000.00$ & 60 & $200,000.00$ & 40 & - & - \\
7 & $800,000.00$ & $500,000.00$ & 62,5 & $300,000.00$ & 60 & $200,000.00$ & 40 & - & - \\
8 & $1,700,000.00$ & $1,000,000.00$ & 58,8 & $700,000.00$ & 70 & $300,000.00$ & 30 & - & - \\
9 & $3,500,000.00$ & $2,500,000.00$ & 71,4 & $2,000,000.00$ & 80 & $500,000.00$ & 20 & - & - \\
10 & $1,400,000.00$ & $1,000,000.00$ & 71,4 & $500,000.00$ & 50 & $350,000.00$ & 35 & $150,000.00$ & 15 \\
11 & $1,300,000.00$ & $1,200,000.00$ & 92,1 & $700,000.00$ & 58,3 & $500,000.00$ & 41,4 & - & - \\
12 & $1,300,000.00$ & $1,000,000.00$ & 76,9 & $700,000.00$ & 70 & $300,000.00$ & 30 & - & - \\
13 & $3,600,000.00$ & $2,500,000.00$ & 69,4 & $700,000.00$ & 28 & $500,000.00$ & 20 & $1,300,000.00$ & 52 \\
14 & $1,000,000.00$ & $600,000.00$ & 60 & $300,000.00$ & 50 & $300,000.00$ & 50 & - & - \\
15 & $4,100,000.00$ & $3,500,000.00$ & 85,3 & $2,000,000.00$ & 57,1 & $700,000.00$ & 20 & $800,000.00$ & 22,9 \\
16 & $900,000.00$ & $400,000.00$ & 44,4 & $200,000.00$ & 50 & $200,000.00$ & 50 & - & - \\
\hline Jumlah & $34,865,000.00$ & $25,400,000.00$ & & & & & & \\
\hline Rata - rata & $2,179,062.50$ & $1,587,500.00$ & 60 & $856,250.00$ & 59 & $465,625.00$ & 33.5 & $265,625.00$ & 7.5 \\
\hline
\end{tabular}

Sumber: Diolah dari Data Primer, 2015

Dari Tabel 8 dapat dilihat jumlah pengeluaran ratarata rumah tangga responden adalah sebesar Rp1.587.500,00 per bulan dan persentase rata-rata pengeluaran ialah $60 \%$. Adapun maksud dari pengeluaran sandang, pangan dan papan ialah sebagai berikut: sandang adalah pengeluaran masyarakat yang meliputi pakaian, sekolah anak, listrik, operasional keluarga, kesehatan. Rata-rata pengeluaran untuk kebutuhan sandang adalah Rp856.250,00 dengan persentase 59\% dari rata-rata pengeluaran. Kebutuhan pangan ialah biaya konsumsi makanan keluaraga sehari-hari dengan ratarata pengeluaran $\mathrm{Rp} 465.625,00$ dengan persentasi $33,5 \%$ dari rata-rata pengeluaran. Papan adalah pengeluaran untuk biaya perumahan seperti perbaikan sarana rumah/tempat tinggal dan memiliki ratarata pengeluaran sebesar Rp265.625,00 dengan persentase sebesar 7,5\%. Itu berarti pengeluaran terbanyak masyarakat di desa Bahoi adalah pengeluaran untuk sandang. Berdasarkan hasil wawancara, pengeluaran untuk sandang mengalami peningkatan karena kebutuhan dari rumah tangga yang meningkat dengan adanya ekowisata seperti 
biaya listrik bertambah jika rumah masyarakat dijadikan homestay, pakaian karena banyaknya wisatawan masyarakat harus lebih rapi dalam berpakaian, biaya operasional karena masyarakat yang menjadi pemandu (gude diving) harus mengisi bahan bakar perahu yang digunakan, biaya sekola anak karena dengan naiknya semua kebutuhan pasti kebutuhan anak sekolah pun ikut naik seperti jajan anak, SPP, buku pelajaran dan lain sebagainya. Sedangkan pangan berada di posisi kedua untuk biaya pengeluaran, disebabkan pengeluaran untuk pangan hanya mencakup kebutuhan makan sehari-hari. Adapun peningkatan kebutuhan pangan dari hasil wawancara dengan responden hanyalah masyarakat yang memberikan jasa menjual makanan dan penjual jajanan (warung). Kebututuhan untuk papan adalah pengeluaran paling kecil dari masyarakat. Ini disebabkan kebutuhan untuk papan belum terlalu dibutuhkan karena dari hasil penelitian di lapangan rata-rata rumah dari masyarakat ialah permanen dan hanya sebagian kecil rumah masyarakat yang belum permanen. Dari wawancara dengan responden kebutuhan papan yang meningkat ialah rumah masyarakat yang dijadikan homestay disebabkan masyarakat harus menambah ruangan untuk kamar dan perlengkapan tidur (kasur dan bantal) dan memperbaiki sarana WC dan kamar mandi. Ada juga warga yang merenovasi rumah mereka karena ada tambahan penghasilan.

\section{Kondisi Perumahan}

Perumahan merupakan salah satu kebutuhan pokok masyarakat yang sangat penting dalam pencapaian kehidupan yang layak, di samping sandang dan pangan serta kesehatan dan pendidikan. Meski demikian, tidak semua masyarakat mampu memenuhi kebutuhan pokok akan perumahan tersebut. Bahkan tidak sedikit warga masyarakat yang tidak mampu memiliki rumah sepanjang hidupnya. Oleh karena itu kondisi perumahan dapat dijadikan sebagai salah satu indikator tingkat kesejahteraan ekonomi masyarakat. Baiknya kondisi perumahan rumah tangga/keluarga merupakan salah satu indicator semakin tingginya taraf hidup keluarga tersebut.
Kondisi perumahan masyarakat desa Bahoi dilihat dari kondisi dari beberapa tolak ukur seperti jenis atap, bilik, status rumah, lahan, dan luas lahan, terdiri dari permanen, semi permanen, tidak permanen dapat dilihat dari tabel 10 .

Tabel 9. Kondisi Perumahan

KONDISI PERUMAHAN SEBELM DAN SESUDAH MASUKNYA EKOWISATA

\begin{tabular}{cccccccc}
\hline & TIDAK PERMANEN & $\begin{array}{c}\text { SEMI PERMANEN } \\
\text { PERSEN } \\
\text { JUMLAH }\end{array}$ & PERSEN (\%) & PUMLAHANEN & $\begin{array}{c}\text { JUMLAH } \\
\text { SAMPEL }\end{array}$ & JUMLAH PERSEN $(\%)$ & \\
\hline $\begin{array}{c}\text { SEBELUM MASUK } \\
\text { EKOWISATA }\end{array}$ & 0 & $0 \%$ & 6 & $37,5 \%$ & 10 & $62,5 \%$ & 16 \\
$\begin{array}{c}\text { SESUDAHMASUK } \\
\text { EKOWISATA }\end{array}$ & 0 & $0 \%$ & 4 & $25 \%$ & 12 & $75 \%$ & 16 \\
\hline RATA-RATA & & & & $0,25 \%$ & & $75 \%$ & \\
\hline
\end{tabular}

Berdasarkan tabel 9, dapat dilihat bahwa sebelum masuknya ekowisata jumlah rumah yang semi permanen sebanyak 6 dengan persentase $37,5 \%$ dan rumah yang permanen sebanyak 10 dengan persentase $62,5 \%$ setelah masuknya ekowisata dapat dilihat ada peningkatan yakni rumah semi permanen menjadi 4 dengan persentase $25 \%$ dan rumah yang permanen menjadi 12 dengan persentase $75 \%$. Hal ini disebabkan pendapatan masyarakat meningkat dan untuk mendukung program ekowisata sebagian rumah warga dibuat menjadi homestay dan juga masyarakat yang memang hanya menambah fasilitas rumah mereka karena pendapatan mereka meningkat karena terlibat dalam kegiatan ekowisata. Berdasarkan kondisi perumahan yang dimiliki responden tersebut terlihat bahwa kesejahteraan masyarakat baik.

Hal ini menunjukan bahwa aktivitas masyarakat dalam kegiatan ekowisata di desa Bahoi dapat mempengaruhi kondisi perumahan. Keadaan ini disebabkan oleh pentingnya arti perumahan bagi masyarakat di wilayah ini, di mana rumah tidak hanya sebagai tempat berteduh akan tetapi kondisi perumahan cermin status sosial masyarakat yang ada di desa Bahoi. Dengan semakin meningkatnya pendapatan yang diperoleh, kondisi perumahan masyarakatpun juga meningkat. 


\section{Peranan Ekowisata dan Kesejahteraan Masyarakat di Desa Bahoi}

Ekowisata di desa Bahoi sangatlah berperan penting terhadap kelangsungan hidup masyarakat karena dengan adanya ekowisata masyarakat dapat merasakan dampaknya secara langsung maupun tidak langsung seperti dapat menambah pendapatan, ilmu dan pengalaman yang lebih dari kegiatan ekowisata. Pendapatan yang dimaksudkan di sini terbagi dari dua yaitu langsung maupun tidak langsung. Pendapatan secara langsung yaitu dengan adanya ekowisata masyarakat yang terlibat dapat menjadi pemandu wisata, penjual makanan, sewa perahu dan jasa home stay yang dapat menambah pendapatan dari jasa yang diberikan, sedangkan pendapatan tidak langsung yaitu masyarakat yang tidak terlibat dapat merasakannya juga dari pengunjung yang datang dengan membeli makanan, minuman serta aneka kerajinan tangan yang dijual. Ilmu dan pengalaman yang dimaksudkan khususnya masyarakat yang terlibat langsung yaitu diberikan pelatihan berbahasa asing serta pengetahuan tentang pariwisata sehingga ketika menjadi pemandu wisata masyarakat yang terlibat dapat berkomunikasi dengan baik dengan wisatawan lokal mupun asing. Tabel 10 menunjukkan usaha ekowisata penduduk desa Bahoi.

Dari Tabel 10 dapat dilihat bahwa peranan ekowisata dalam usaha masyarakat sangatlah penting karena dengan adanya usaha ekowisata, masyarakat dapat terlibat dalam kegiatan ekowisata seperti yang sudah dijelaskan di Tabel 6 dan pastinya dapat meningkatkan pendapatan masyarakat setempat

Dalam rangka mempertahankan kehidupan dan meningkatkan kesejahteraan, masyarakat di desa Bahoi melakukan pemanfaatan semua sumber daya yang ada khususnya sumber daya alam, sumber daya manusia dan sumber daya buatan dalam berbagai aktivitas masyarakat termasuk di antaranya aktivitas ekonomi. Aktivitas ekonomi yang dilakukan masyarakat Bahoi selain potensi perikanannya adalah pemanfaatan potensi ekowisata yang bertujuan untuk meningkatkan perekonomian kawasan dan kesejahteraan masyarakat. Dampaknya adalah dengan bertambahnya pendapatan masyarakat melalui kegiatan wisata, seperti home stay, kerajinan tangan, diving, snorkeling, trekking, dan penjualan makanan dapat meningkatkan kesejahteraan masyarakat itu sendiri.

Tabel 10. Usaha Ekowisata Penduduk Desa Bahoi

\begin{tabular}{cccc}
\hline No & Jenis usaha & $\begin{array}{c}\text { jumlah } \\
\text { (pengelola) }\end{array}$ & $\begin{array}{c}\text { jumlah } \\
\text { (Orang) }\end{array}$ \\
\hline 1 & Pemandu wisata & 1 & 5 \\
2 & penjual makanan & 1 & 5 \\
3 & Sewa Perahu & 3 & 2 \\
4 & Home Stay & 4 & 4 \\
\hline & Jumlah & 9 & 16
\end{tabular}

Sumber: Diolah dari Data Primer, 2015.

Dari indikator tingkat kesejahteraan dapat dilihat sebelum masuknya ekowisata dan setelah adanya ekowisata di desa Bahoi. Masyarakat yang dulunya hanya bergantung pada mata pencaharian utama, dengan masuknya ekowisata mereka dapat tambahan pekerjaan contohnya yang dulu masyarakat hanya menjadi nelayan setelah adanya ekowisata masyarakat dapat menjadi pemandu wisata (guide), rumah mereka bisa dibuat homestay, perahu yang mereka gunakan untuk mencari ikan dapat disewakan, mereka bisa menjual aneka makanan sehingga otomatis pendapatan masyarakat akan bertambah dan tingkat kesejahteraan pun akan meningkat. Selain itu, dengan adanya ekowisata pengetahuan masyarakat pun akan bertambah karena masyarakat diberikan pelatihan tentang ekowisata dan bahasa asing agar supaya masyarakat dapat berkomunikasi secara baik dengan turis lokal maupun mancanegara yang datang berkunjung. Selain itu pula, masyarakat yang tidak terlibat langsung dalam kegiatan ekowisata dapat merasakan dampak yang positif juga karena setelah adanya ekowisata jumlah pengunjung ke desa akan bertambah dan masyarakat yang memiliki warung makan atau warung jajanan pasti akan mendapat keuntungan 
karena pasti pengunjung akan berbelanja di warung-warung warga dan otomatis pendapatan akan meningkat dan kesejahteraan masyarakat pun ikut meningkat.

\section{KESIMPULAN DAN SARAN}

\section{Kesimpulan}

Berdasarkan penelitian dapat di simpulkan bahwa kegiatan ekowisata yang dilaksanakan di desa Bahoi berperan dalam meningkatkan pendapatan masyarakat secara langsung maupun tidak langsung dan kegiatan ekowisata ini memberikan dampak positif untuk kesejahteraan masyarakat dan di harapkan ekowisata di desa Bahoi kedepannya dapat menaikan kesejahteraan masyarakat secara menyeluruh.

\section{Saran}

Beberapa saran yang dapat di kemukakan secara umum dari hasil penelitian adalah :

Dalam mendukung penyediaan tenaga kerja lokal, dimana saat ini tingkat pendidikan rendah relatif sehingga perluh diupayakan pemberian kursus - kursus bahasa inggris tingkat dasar dan pelatihan teknis untuk pembuatan souvenir menjadi produk - produk bernilai tambah.

Untuk pemerintah daerah perluh meningkatkan program pengendalian pemanfaatan perairan yang bersifat deduktif, kususnya menyangkut pengendalian dan pengawasan pemanfaatan areal terumbu karang dengan melibatkan masyarakat yang pedulu lingkungan dan pemuka adat dan juga perlu di buat fasilitas umum seperti WC umum dan sarana air bersih.

\section{DAFTAR PUSTAKA}

Achyaruddin, 2011. Pengembangan Potensi Ekowisata Berbasis Teknologi Informasi. Dirjen Pengembangan Destinasi Pariwisata
Brahmantyo, H., dan Kusmayadi, 1999. Potensi dan Peluang Usaha dalam Pengembangan Pariwisata Gunung Salak Endah

Daud, A. 2012.Tempat Wisata di Sulawesi Utara, Wikipedia Halaman dalam kategori "Tempat wisata di Sulawesi Utara"

Fandeli. C, 2000. Pengusahaan Ekowisata. Fakultas Kehutanan, Universitas Gadjah Mada. Yogyakarta

Hidayati. D, Mujiyani, Rachmawati. L, Zailani. A, 2003. Ekowisata Pembelajaran dari Kalimantan Timur. Pustaka Sinar Harapan dan LIPI, Jakarta

Hertanto H. B., 2009. Prinsip dan Kriteria Ekowisata Berbasis Masyarakat, Dirjen Pengembangan Destinasi Pariwisata Departemen Kebudayaan dan Pariwisata dan WWF Indonesia Irsyad

Iryenal, 2010 . Iternatif pariwisata yang ramah terhadap lingkungan.fakultas ilmu budaya, universitas indonesia

Maramis, J.B., 2011Strategi Pengembangan

\begin{tabular}{|c|c|c|c|}
\hline Pariwisat & Dengan & & ndekatan \\
\hline Konektivi & tas Antar & Objel & Wisata \\
\hline Dalam Ko & nteks Eco-V & Wisata & Kota \\
\hline Manado & Sulawesi & Utara. & Fakultas \\
\hline Ekonomi & Universitas & Sam & Ratulangi \\
\hline
\end{tabular}
Mahdayani. W., 2009. Buku Panduan Dasar Pelaksanaan Ekowisata. Dinas Pariwisata dan Kebudayaan Kabupaten Nias Selatan

Nugroho. I, 2004. Buku Ajar Ekoturisme. Program Studi Agribisnis, Fakultas Pertanian, Universitas Widyagama. Malang

Siregar , 2009. Memaknai Ecoturisem dan

Pengembangan Berkelanjutan.Agenda

Pariwisata untuk Pengembangan Kualitas Hidup Secara Berkelanjut-an.Badan Penelitan dan Pengembangan, Pemerinta Provinsi Sumatera Utara

Singarimbun M ,dan Effendi S, 1982. Metode Penelitian dan Survey. LP3ES. Jakarta.

Subadra, 2008. Akademi Pariwisata Triatma Jaya-DalungEkowisata sebagai Wahana Pelestarian Alam. Akademi Pariwisata Triatma Jaya-Dalung 
Peranan Ekowisata .....................................(Reydi Manahampi, Leonardus Rengkung, Yolanda Rori, Jean Timban)

Tasidjawa, S., 2012, Membangun Ekowisata

Mandiri di Bahoi Wildlife Conserva-

tion Society Indonesia Program (WCS-

IP)

Undang - undang No 11 Tahun 2009 tentang Kesejahteraan Sosial. 